\title{
HTLV-1 associated bronchiectasis among Indigenous Australians is associated with higher HTLV-1 proviral loads: Results of a prospective case-control study
}

\author{
Lloyd Einsiedel ${ }^{1 *}$, Olivier Cassar ${ }^{2,3}$, Emma Goeman $^{4}$, Tim Spelman $^{1}$, Antoine Gessain ${ }^{2,3}$ \\ From 16th International Conference on Human Retroviruses: HTLV and Related Viruses \\ Montreal, Canada. 26-30 June 2013
}

Infection with HTLV-1 is associated with bronchiectasis in Indigenous Australians. Previous studies have not determined HTLV-1 proviral loads (pvl), which predict risk of other HTLV-1 associated inflammatory diseases, such as HTLV-1 associated myelopathy. Thirty-six Indigenous adults admitted to Alice Springs Hospital, June 2008 to December 2009, with radiologically confirmed bronchiectasis, but no other HTLV-1 related disease, were prospectively recruited and matched by age and sex to 36 controls of the same ethno-geographic origin. Case notes were reviewed from date of birth or first admission to date of recruitment. HTLV-1 subtype C pvl were determined at the Pasteur Institute, Paris. HTLV-1 infection was more common among cases (25/ $36 ; 69.4 \%)$ than their controls $(15 / 36 ; 41.7 \%)(\mathrm{p}<0.018)$. Two cases were admitted in childhood with probable infective dermatitis and two with recurrent strongyloidiasis unresponsive to treatment with thiabendazole. In adulthood, cases $(25 / 36 ; 69 \%)$ were more likely than controls $(5 / 25 ; 20 \%)$ to have positive or borderline strongyloides serology $(\mathrm{p}<0.001)$. The mean HTLV-1 pvl $( \pm$ SEM $)$ was significantly higher for cases $(0.83 \pm 0.21 \%$ PBMC) than controls $(0.12 \pm 0.05 \%$ PBMC $)(p=0.016)$ and was nearly17 fold-higher compared to controls in which bronchiectasis was excluded by HRCT $(0.05 \pm 0.02 \%$ PBMC; $\mathrm{p}=0.006)$. Twelve cases $(33.3 \%)$ and 5 controls $(13.9 \%)$ died during 3 years of follow-up $(\mathrm{p}<0.052)$. Cases died at a younger age (cases, $49 \pm 15$; controls, $60 \pm 13)(\mathrm{p}=0.15)$. In both groups HTLV-1 infected

\footnotetext{
* Correspondence: Lloyd.Einsiedel@health.sa.gov.au

'Flinders University/Northern Territory Rural Clinical School, Alice Springs Hospital, Northern Territory, Australia

Full list of author information is available at the end of the article
}

patients were more likely to die: cases, 11/12 (92\%); controls, 4/5 (80\%). HTLV-1-associated bronchiectasis is associated with higher HTLV-1 pvl suggesting that this condition results from an HTLV-1 driven inflammatory process.

\section{Authors' details}

${ }^{1}$ Flinders University/Northern Territory Rural Clinical School, Alice Springs Hospital, Northern Territory, Australia. ${ }^{2}$ Institut Pasteur, Unité d'Epidémiologie et Physiopathologie des Virus Oncogènes, Département de Virologie, Paris, France. ${ }^{3}$ CNRS, UMR 3569, Paris, France. ${ }^{4}$ Department of Paediatrics, Alice Springs Hospital, Northern Territory, Australia.

Published: 7 January 2014

\section{doi:10.1186/1742-4690-11-S1-P28}

Cite this article as: Einsiedel et al: HTLV-1 associated bronchiectasis among Indigenous Australians is associated with higher HTLV-1 proviral loads: Results of a prospective case-control study. Retrovirology 201411 (Suppl 1):P28.

Submit your next manuscript to BioMed Central and take full advantage of:

- Convenient online submission

- Thorough peer review

- No space constraints or color figure charges

- Immediate publication on acceptance

- Inclusion in PubMed, CAS, Scopus and Google Scholar

- Research which is freely available for redistribution

Submit your manuscript at www.biomedcentral.com/submit

\section{() Biomed Central}

